\title{
PENGARUH KADAR INTERLEUKIN-6 DAN NEURON SPECIFIC ENOLASE TERHADAP LUARAN STROKE ISKEMIK AKUT
}

\author{
THE EFFECT OF INTERLEUKIN-6 AND NEURON SPECIFIC ENOLASE LEVEL \\ ON ACUTE ISCHEMIC STROKE OUTCOME WITH PACS AND LACS SUBTYPE
}

\author{
Al Rasyid, * Salim Harris, * Muhammad Kurniawan, * Taufik Mesiano, * Rakhmad Hidayat*
}

\section{ABSTRACT}

Introduction: Brain blood flow disruption in ischemic stroke will trigger cells damage cascade and caused infarction. Interleukin-6 (IL-6) and neuron specific enolase (NSE) are brain cells damage marker that can be markers of acute ischemic stroke outcome.

Aim: To investigate the effect of IL-6 and NSE levels on acute ischemic stroke outcome and its interacting factors.

Methods: An observational cohort study on ischemic stroke patients with onset $\leq 3$ days in several hospitals in Jakarta and Depok in 2014. Medical history and physical examination were carried out as well as laboratory parameters; hematocrit, fibrinogen, low density lipoprotein (LDL), high density lipoprotein (HDL), triglyceride, IL-6, and NSE. The National Institute of Health Stroke Scale (NIHSS) were assessed $\leq 72$ hours of onset and 7 days along with Modified Rankin Scale (mRS) at 1 month of onset. Bivariate and multivariate logistic regression were done to investigate the association of $I L-6$ and NSE with stroke outcome and other factors.

Results: One-hundred thirty-five subjects were included, mostly male (62\%), with age mean 59,4 10,7 years and subtype PACS (76\%). Interleukin-6 and NSE level were elevated in $61,5 \%$ and $21,5 \%$ subjects. Interleukin-6 and fibrinogen influenced the $m R S$, while diabetes and fibrinogen influenced the NIHSS. NSE serum didn't show any association with $m R S$ nor NIHSS, but influenced by dyslipidemia.

Discussion: There was a tendency of worse outcome on high IL-6 level patients, although by multivariate analysis IL-2 alone was not sufficient enough as prognostic marker in acute ischemic stroke outcome. Neuron specific enolase serum didn't show any association with acute stroke outcome due to also influenced by sex, smoking, and fibrinogen levels.

Keywords: Acute ischemic stroke, IL-6, NSE, outcome

\section{ABSTRAK}

Pendahuluan: Gangguan aliran darah otak pada stroke iskemik akut akan memicu kaskade kerusakan sel otak yang menyebabkan infark dan inflamasi. Interleukin-6 (IL-6) dan neuron specific enolase (NSE) merupakan penanda kerusakan sel otak yang dapat menjadi penanda luaran stroke iskemik akut.

Tujuan: Mengetahui pengaruh kadar IL-6 dan NSE pada luaran stroke iskemik akut serta faktor-faktor yang memengaruhinya.

Metode: Penelitian kohort observasional terhadap pasien stroke iskemik akut dengan awitan $\leq 3$ hari yang dirawat di beberapa RS di Jakarta dan Depok pada tahun 2014. Dilakukan anamnesis dan pemeriksaan fisik serta pemeriksaan hematokrit, fibrinogen, low density lipoprotein (LDL), high density lipoprotein (HDL), trigliserida, IL-6, dan NSE serum. Dilakukan pemeriksaan National Institute of Health Stroke Scale (NIHSS) awal awitan $\leq 72$ jam dan 7 hari serta modified rankin scale (mRS) pada 1 bulan. Analisis statistik bivariat dan regresi logistik multivariat dilakukan untuk mengetahui hubungan kadar IL-6 dan NSE dengan luaran stroke serta hubungannya terhadap faktor-faktor lainnya.

Hasil: Didapatkan 135 subjek yang mayoritas laki-laki (62\%) dengan rerata usia 59,4 $\pm 10,7$ tahun dan subtipe PACS (76\%). Peningkatan kadar IL-6 dan NSE ditemukan pada 61,5\% dan 21,5\% subjek. Luaran berdasarkan skor mRS dipengaruhi oleh kadar IL-6 dan fibrinogen, sedangkan berdasarkan NIHSS dipengaruhi oleh diabetes melitus dan fibrinogen. Kadar NSE tidak berhubungan dengan mRS dan NIHSS, namun dipengaruhi oleh status dislipidemia.

Diskusi: Terdapat kecenderungan luaran buruk pada kadar IL-6 tinggi, namun dengan analisis multivariat IL-6 belum bisa menjadi penanda prognosis luaran stroke iskemik akut. Kadar NSE serum tidak berperan terhadap luaran stroke iskemik akut, oleh karena juga dipengaruhi oleh jenis kelamin, merokok, dan kadar fibrinogen.

Kata kunci: Stroke iskemik akut, IL-6, neuron specirefic enolase, luaran

*Departemen Neurologi FK Universitas Indonesia/RSUPN Dr. Cipto Mangunkusumo, Jakarta. Korespondensi: alrasyid50@yahoo.com. 


\section{PENDAHULUAN}

Gangguan aliran darah otak pada stroke iskemik akut akan memicu kaskade kerusakan sel otak yang menyebabkan infark dan selanjutnya memicu respons inflamasi. Stres oksidatif dan eksitotoksisitas yang diakibatkan infark akan memicu mikroglia dan astrosit menghasilkan enzim-enzim proteolitik dan sitokin pro-inflamasi, seperti TNF- $\alpha$, IL-1 $\beta$, dan interleukin 6 (IL-6). ${ }^{1-2}$

Interleukin 6 merupakan salah satu mediator inflamasi awal yang berperan dalam stroke iskemik akut. ${ }^{3-4}$ Cojocaru dkk menunjukkan bahwa kadar IL-6 akan meningkat pada 24 jam pertama pascastroke. ${ }^{3}$ Demikian pula Shenhar-Tsarfaty dkk mendapatkan bahwa IL-6 berperan dalam volume infark dan keparahan stroke. ${ }^{5}$

Penanda lain yang dapat digunakan untuk menilai klinis dan prognosis luaran stroke adalah neuron specific enolase (NSE). Enzim ini melakukan katalis pelepasan molekul $\mathrm{H}_{2} \mathrm{O}$ dari 2-fosfogliserat menjadi fosfoenol piruvat yang terdapat pada proses glikolisis..$^{3-6}$ Terdapat peningkatan NSE pada subjek yang mengalami stroke, seperti yang dilakukan oleh Zaheer dkk, adanya peningkatan serum NSE yang bermakna antara subjek dengan luaran stroke akut. ${ }^{7}$

Sekresi IL-6 pada otak akan memicu migrasi makrofag dan neutrofil ke area infark. Sel-sel imun tersebut akan melepaskan IL-6 lebih lanjut dan meningkatkan kadar IL-6. Oleh karena itu, peningkatan IL-6 menggambarkan kerusakan penumbra dan perburukan luaran stroke. ${ }^{8}$ Benakis dkk menyatakan bahwa IL-6 dapat menggambarkan luas area iskemik pada area otak yang teroklusi. ${ }^{4}$ Kusumaningrum menunjukkan kadar IL-6 memengaruhi luaran stroke akut antara 1 dan 3 bulan menggunakan modified Rankin Scale (mRS). ${ }^{9}$

Penelitian Anand dkk menunjukkan bahwa kadar NSE dalam darah berhubungan dengan skor National Institutes of Health Stroke Scale (NIHSS) pada saat masuk. ${ }^{10}$ Selain itu, kadar NSE juga berkorelasi dengan volume infark. ${ }^{7}$ Namun sejauh ini belum ada penelitian mengenai kadar NSE dan IL-6 saat admisi dengan luaran stroke agar dapat digunakan sebagai penanda prognosis pada stroke iskemik akut.

\section{TUJUAN}

Mengetahui pengaruh kadar NSE dan IL-6 terhadap luaran berdasarkan skor mRS dan NIHSS dengan menyesuaikan terhadap faktor-faktor perancu.

\section{METODE}

Penelitian ini merupakan penelitian kohort observasional yang dilakukan di Departemen Neurologi RSUPN Dr. Cipto Mangunkusumo, Jakarta; RS Bhakti Yuda, Depok; RS Prikasih, Jakarta; dan RSUP Fatmawati, Jakarta tahun 2014. Kriteria inklusi adalah subjek berusia 35-74 tahun stroke iskemik akut dan infark dengan awitan $\leq 3$ hari dengan gejala klinis partial anterior circulatory stroke (PACS) atau lacunar circulatory stroke (LACS). Adapun tipe posterior circulatory stroke (POCS) sulit dinilai dengan skala NIHSS adanya gangguan batang otak, demikian pula tipe total anterior circulatory stroke (TACS) tidak diikutkan dalam penelitian karena gejala klinis yang sangat berat. ${ }^{11-12}$

Kriteria eksklusi adalah subjek dengan riwayat transient ischemic attack (TIA), memiliki penyakit yang memengaruhi viskositas dan plasma darah seperti anemia, polisitemia, demam berdarah dengue (DBD), perdarahan masif, status hipovolemik, kejang, trauma kepala, menderita tumor otak, memiliki riwayat infeksi otak, serta Ca paru aktif.

Subjek dilakukan pemeriksaan kadar hematokrit, fibrinogen, low density lipoprotein (LDL), high density lipoprotein (HDL), trigliserida, IL-6, dan NSE serum, sebelum mendapatkan cairan infus atau obat-obatan yang memengaruhi aktivitas hemoreologik darah. Setelah itu, dilakukan pemeriksaan skor NIHSS pada hari ke-3 dan 7 serta skor mRS pada 1 bulan pascaawitan. Luaran dikatakan baik jika skor NIHSS 0 atau berkurang $\geq 4$ poin dan dinyatakan baik jika skor NIHSS bertambah $\geq 1$ poin atau tidak ada perbaikan. Skor mRS $\leq 2$ merupakan luaran baik, sebaliknya skor $>2$ merupakan luaran buruk. Nilai IL-6 dan NSE dalam darah dinyatakan tinggi jika kadarnya masing-masing $\geq 7 \mathrm{pg} / \mathrm{mL}$ dan $\geq 16 \mu \mathrm{g} / \mathrm{L} .{ }^{11}$

Penelitian ini mendapat persetujuan Komisi Etik Penelitian Kesehatan Fakultas Kedokteran Universitas Indonesia No:69/H2.F1/ETIK/2013. Analisis statistik menggunakan program SPSS; uji 
Tabel 1. Karakteristik Demografi Subjek $(n=135)$

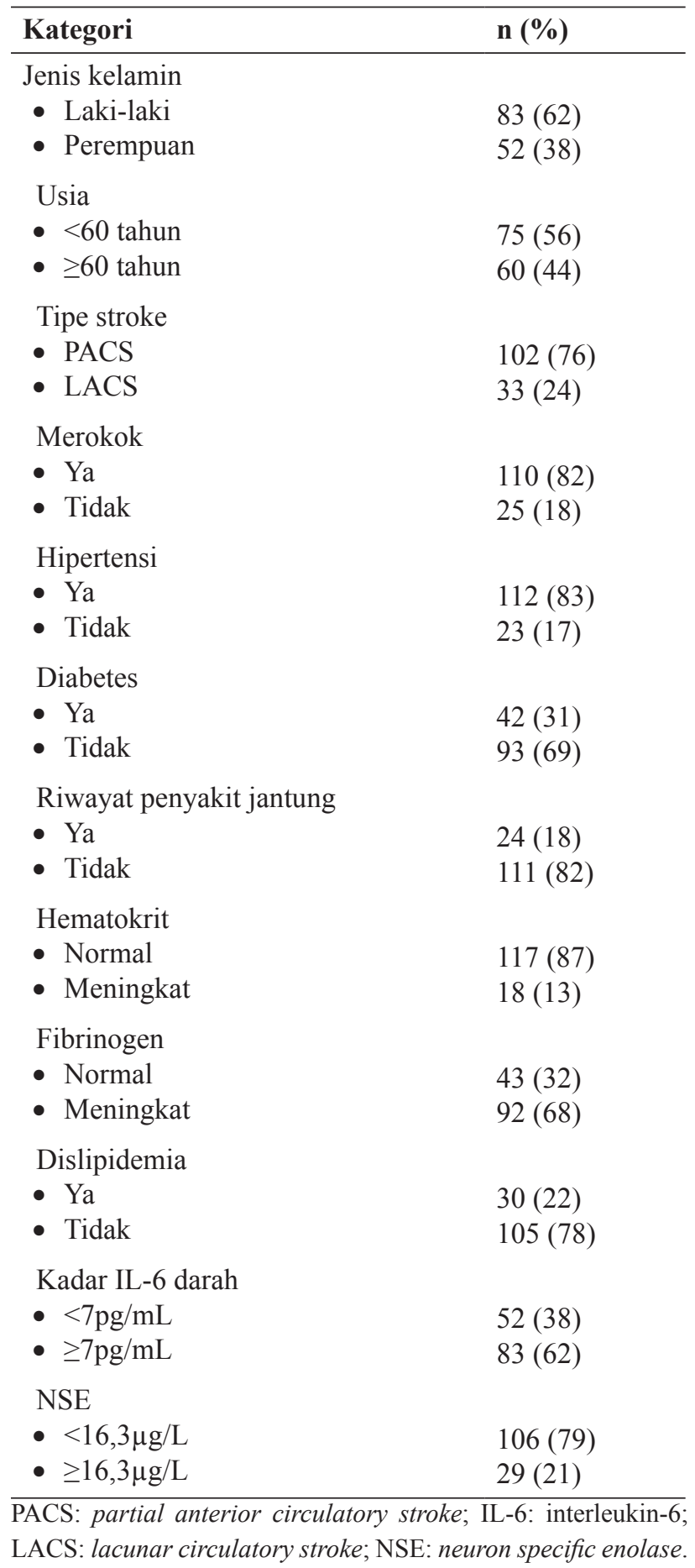

Chi-square untuk analisis bivariat terhadap faktorfaktor yang memengaruhi perubahan skor NIHSS dan mRS pascastroke. Analisis multivariat dilakukan pada variabel yang memiliki $\mathrm{p}<0,25$ berdasarkan analisis bivariat. Uji multivariat regresi logistik dilakukan untuk mengetahui pengaruh IL-6 dan NSE terhadap luaran subjek stroke iskemik akut yang disesuaikan dengan faktor-faktor perancu lainnya.

\section{HASIL}

Didapatkan 135 subjek penelitian (Tabel 1) yang mayoritas laki-laki (62\%) dengan rerata usia $59,4 \pm 10,7$ tahun, memiliki stroke tipe PACS (76\%) dengan kadar IL-6 yang meningkat $(\geq 7 \mathrm{pg} / \mathrm{mL})$ sebanyak $62 \%$ dan kadar NSE normal $(<16 \mu \mathrm{g} / \mathrm{L})$ sebanyak $79 \%$.

Tabel 2 menunjukkan hubungan kadar IL-6 dan NSE dengan mRS dan NIHSS. Sementara itu, analisis terhadap faktor-faktor perancu Skor mRS dipengaruhi oleh kadar IL- 6 dan fibrinogen ( $p=0,007$ dan 0,000). Adapun skor NIHSS dipengaruhi oleh diabetes melitus $(\mathrm{DM})$ dan kadar fibrinogen $(\mathrm{p}=0,034$ dan $\mathrm{p}=0,017$ ) (Tabel 2 dan 3).

Hasil analisis terhadap faktor-faktor perancu kadar IL-6 adalah jenis kelamin $(p=0,004)$ dan fibrinogen $(p=0,039)$. Sedangkan skor NSE dipengaruhi oleh kadar dislipidemia $(\mathrm{p}=0,025)$ (Tabel 4).

Analisis risiko relatif (RR) kadar IL-6 terhadap skor NIHSS dilakukan dengan penyesuaian terhadap beberapa faktor, seperti nilai hematokrit, kadar fibrinogen, dan status dislipidemia. RR adjusted kadar IL-6 terhadap perburukan klinis subjek (Tabel 5) dengan peningkatan skor NIHSS adalah 1,279 (interval kepercayaan/IK 95\% 0,581-2,812).

Dalam analisisnya, terdapat 2 faktor perancu yang berinteraksi dengan kadar IL-6 terhadap luaran mRS subjek yaitu jenis kelamin dan status merokok. Analisis nilai RR kadar IL-6 dan mRS dengan interaksinya terhadap kedua faktor tersebut dapat dilihat pada Tabel 6. Analisis kadar IL-6 terhadap luaran mRS menunjukkan subjek perempuan dengan riwayat merokok yang memiliki kadar IL-6 tinggi cenderung untuk mempunyai luaran klinis buruk berupa peningkatan skor mRS 181,5 (IK 95\% 0,43-77029) kali dibandingkan yang memiliki IL-6 normal.

\section{PEMBAHASAN}

Sebagian besar subjek dalam penelitian ini adalah laki-laki. Hal ini sesuai dengan Bushnell dkk yang mendapatkan insidens stroke pada lakilaki lebih besar dibandingkan perempuan dengan $54 \%$ populasi merupakan laki-laki. ${ }^{13}$ Pada proporsi subjek berusia $<60$ tahun dan $\geq 60$ tahun didapatkan 
Tabel 2. Analisis Bivariat IL-6 dan NSE terhadap Luaran mRS dan NIHSS (n=135)

\begin{tabular}{|c|c|c|c|c|c|c|}
\hline \multirow[b]{2}{*}{ Variabel } & \multicolumn{2}{|c|}{ mRS } & \multirow[b]{2}{*}{$\mathbf{p}$} & \multicolumn{2}{|c|}{ NIHSS } & \multirow[b]{2}{*}{$\mathbf{p}$} \\
\hline & $\begin{array}{l}\text { Baik } \\
\text { n (\%) }\end{array}$ & $\begin{array}{l}\text { Buruk } \\
\text { n (\%) }\end{array}$ & & $\begin{array}{c}\text { Perbaikan } \\
\text { n (\%) }\end{array}$ & $\begin{array}{c}\text { Perburukan } \\
\text { n (\%) }\end{array}$ & \\
\hline $\begin{array}{l}\text { Kadar IL-6 } \\
\text { - Tinggi } \\
\text { - Normal }\end{array}$ & $\begin{array}{l}24(47) \\
27(53)\end{array}$ & $\begin{array}{l}59(70) \\
25(30)\end{array}$ & $0,017^{*}$ & $\begin{array}{l}22(54) \\
19(46)\end{array}$ & $\begin{array}{l}61(65) \\
33(35)\end{array}$ & 0,217 \\
\hline $\begin{array}{l}\text { Kadar NSE } \\
\text { - Tinggi } \\
\text { - Normal }\end{array}$ & $\begin{array}{l}9(18) \\
42(82)\end{array}$ & $\begin{array}{l}20(24) \\
64(76)\end{array}$ & 0,398 & $\begin{array}{l}8(20) \\
33(80)\end{array}$ & $\begin{array}{l}21(22) \\
73(78)\end{array}$ & 0,713 \\
\hline
\end{tabular}

Tabel 3. Analisis Bivariat Faktor-faktor Perancu Kadar IL-6 dan NSE terhadap Luaran mRS dan NIHSS (n=135)

\begin{tabular}{|c|c|c|c|c|c|c|}
\hline \multirow[b]{2}{*}{ Variabel } & \multicolumn{2}{|c|}{ mRS } & \multirow[b]{2}{*}{$\mathbf{p}$} & \multicolumn{2}{|c|}{ NIHSS } & \multirow[b]{2}{*}{$\mathbf{p}$} \\
\hline & $\begin{array}{l}\text { Baik } \\
\text { n (\%) }\end{array}$ & $\begin{array}{l}\text { Buruk } \\
\text { n (\%) }\end{array}$ & & $\begin{array}{c}\text { Perbaikan } \\
\text { n }(\%) \\
\end{array}$ & $\begin{array}{c}\text { Perburukan } \\
\text { n (\%) }\end{array}$ & \\
\hline $\begin{array}{l}\text { Umur } \\
\bullet \geq 60 \text { tahun } \\
\cdot<60 \text { tahun }\end{array}$ & $\begin{array}{l}21(41) \\
30(59)\end{array}$ & $\begin{array}{l}39(46) \\
45(54)\end{array}$ & 0,552 & $\begin{array}{l}21(51) \\
20(49)\end{array}$ & $\begin{array}{l}39(41) \\
55(59)\end{array}$ & 0,295 \\
\hline $\begin{array}{l}\text { Jenis kelamin } \\
\text { - Laki-laki } \\
\text { - Perempuan }\end{array}$ & $\begin{array}{l}35(69) \\
16(31)\end{array}$ & $\begin{array}{l}48(57) \\
36(43)\end{array}$ & 0,184 & $\begin{array}{l}30(73) \\
11(27)\end{array}$ & $\begin{array}{l}53(56) \\
41(44)\end{array}$ & 0,065 \\
\hline $\begin{array}{l}\text { Merokok } \\
\text { - Ya } \\
\text { - Tidak }\end{array}$ & $\begin{array}{l}12(24) \\
39(76)\end{array}$ & $\begin{array}{l}13(15) \\
71(85)\end{array}$ & 0,243 & $\begin{array}{l}35(85) \\
6(15)\end{array}$ & $\begin{array}{l}75(80) \\
19(20)\end{array}$ & 0,443 \\
\hline $\begin{array}{l}\text { Hipertensi } \\
\text { - Ya } \\
\text { - Tidak }\end{array}$ & $\begin{array}{l}42(82) \\
9(18)\end{array}$ & $\begin{array}{l}70(83) \\
14(17)\end{array}$ & 0,883 & $\begin{array}{l}33(80) \\
8(20)\end{array}$ & $\begin{array}{l}79(84) \\
15(16)\end{array}$ & 0,613 \\
\hline $\begin{array}{l}\text { Diabetes melitus } \\
\text { - Ya } \\
\text { - Tidak }\end{array}$ & $\begin{array}{l}19(46) \\
32(54)\end{array}$ & $\begin{array}{l}23(27) \\
61(73)\end{array}$ & 0,230 & $\begin{array}{l}23(56) \\
18(44)\end{array}$ & $\begin{array}{l}24(26) \\
70(74)\end{array}$ & $0,034 *$ \\
\hline $\begin{array}{l}\text { Riwayat penyakit jantung } \\
\text { - Ya } \\
\text { - Tidak }\end{array}$ & $\begin{array}{l}12(24) \\
39(76)\end{array}$ & $\begin{array}{l}12(17) \\
72(83)\end{array}$ & 0,173 & $\begin{array}{l}7(17) \\
34(83)\end{array}$ & $\begin{array}{l}17(18) \\
77(82)\end{array}$ & 0,888 \\
\hline $\begin{array}{l}\text { Hematokrit } \\
\text { - Meningkat } \\
\text { - Normal }\end{array}$ & $\begin{array}{l}4(8) \\
47(92)\end{array}$ & $\begin{array}{l}14(17) \\
70(83)\end{array}$ & 0,144 & $\begin{array}{l}3(8) \\
38(92)\end{array}$ & $\begin{array}{l}15(16) \\
79(84)\end{array}$ & 0,174 \\
\hline $\begin{array}{l}\text { Fibrinogen } \\
\text { - Meningkat } \\
\text { - Normal }\end{array}$ & $\begin{array}{l}21(41) \\
30(59)\end{array}$ & $\begin{array}{l}71(85) \\
13(15)\end{array}$ & $0,000 *$ & $\begin{array}{l}22(54) \\
19(46)\end{array}$ & $\begin{array}{l}70(74) \\
24(26)\end{array}$ & $0,017^{*}$ \\
\hline $\begin{array}{l}\text { Dislipidemia } \\
\text { - Ya } \\
\text { - Tidak }\end{array}$ & $\begin{array}{l}36(71) \\
15(29)\end{array}$ & $\begin{array}{l}69(82) \\
15(18)\end{array}$ & 0,117 & $\begin{array}{l}28(68) \\
13(32)\end{array}$ & $\begin{array}{l}77(82) \\
17(18)\end{array}$ & 0,080 \\
\hline
\end{tabular}

hampir sama dan hasil ini sesuai dengan penelitian Kusumaningrum yang memiliki proporsi yang tidak jauh berbeda antara 2 kelompok. ${ }^{9}$ Sebagian besar subjek memiliki riwayat merokok dan hipertensi, sesuai dengan Arboix dkk dan Bangalore dkk bahwa merokok dan hipertensi sebagai salah satu faktor risiko terjadinya stroke. ${ }^{14-15}$ Yudiarto dkk menyatakan bahwa $77 \%$ pasien dengan hipertensi dan $27,5 \%$ pasien perokok mengalami stroke. ${ }^{16}$

Belum ada penelitian sebelumnya yang membandingkan perubahan skor NIHSS 7 hari setelah awitan stroke dan hubungannya dengan DM. Nayak 
Tabel 4. Analisis Bivariat Faktor-faktor Perancu Kadar IL-6 dan NSE (n=135)

\begin{tabular}{|c|c|c|c|c|c|c|}
\hline \multirow[b]{2}{*}{ Variabel } & \multicolumn{2}{|c|}{ IL-6 } & \multirow[b]{2}{*}{$\mathbf{p}$} & \multicolumn{2}{|c|}{ NSE } & \multirow[b]{2}{*}{$\mathbf{p}$} \\
\hline & $\begin{array}{l}\text { Normal } \\
\text { n (\%) }\end{array}$ & $\begin{array}{l}\text { Meningkat } \\
\text { n (\%) }\end{array}$ & & $\begin{array}{c}\text { Normal } \\
\text { n (\%) }\end{array}$ & $\begin{array}{c}\text { Meningkat } \\
\text { n (\%) }\end{array}$ & \\
\hline $\begin{array}{l}\text { Umur } \\
-\geq 60 \text { tahun } \\
-<60 \text { tahun }\end{array}$ & $\begin{array}{l}19(31,7) \\
33(44)\end{array}$ & $\begin{array}{l}41(68,3) \\
42(56)\end{array}$ & 0,143 & $\begin{array}{l}46(76,7) \\
60(80)\end{array}$ & $\begin{array}{l}14(23,3) \\
15(20)\end{array}$ & 0,639 \\
\hline $\begin{array}{l}\text { Jenis kelamin } \\
\text { - Laki-laki } \\
\text { - Perempuan }\end{array}$ & $\begin{array}{l}40(48,2) \\
12(23,1)\end{array}$ & $\begin{array}{l}43(51,8) \\
40(76,9)\end{array}$ & $0,004 *$ & $\begin{array}{l}66(79,5) \\
40(76,9)\end{array}$ & $\begin{array}{l}17(20,5) \\
12(23,1)\end{array}$ & 0,721 \\
\hline $\begin{array}{l}\text { Merokok } \\
\text { - Ya } \\
\text { - Tidak }\end{array}$ & $\begin{array}{l}15(60) \\
37(33,6)\end{array}$ & $\begin{array}{l}10(40) \\
73(66,4)\end{array}$ & $0,014^{*}$ & $\begin{array}{l}21(84) \\
85(77,3)\end{array}$ & $\begin{array}{l}4(16) \\
25(22,7)\end{array}$ & 0,460 \\
\hline $\begin{array}{l}\text { Hipertensi } \\
\text { - Ya } \\
\text { - Tidak }\end{array}$ & $\begin{array}{l}47(42) \\
5(21,7)\end{array}$ & $\begin{array}{l}65(58) \\
18(78,3)\end{array}$ & 0,069 & $\begin{array}{l}91(81,3) \\
15(65,2)\end{array}$ & $\begin{array}{l}21(18,8) \\
8(34,8)\end{array}$ & 0,088 \\
\hline $\begin{array}{l}\text { Diabetes melitus } \\
\text { - Ya } \\
\text { - Tidak }\end{array}$ & $\begin{array}{l}12(28,6) \\
40(43)\end{array}$ & $\begin{array}{l}30(71,4) \\
53(57)\end{array}$ & 0,110 & $\begin{array}{l}35(83,3) \\
71(76,3)\end{array}$ & $\begin{array}{l}7(16,7) \\
22(23,7)\end{array}$ & 0,360 \\
\hline $\begin{array}{l}\text { Riwayat penyakit jantung } \\
\text { - Ya } \\
\text { - Tidak }\end{array}$ & $\begin{array}{l}11(45,8) \\
41(36,9)\end{array}$ & $\begin{array}{l}13(54,2) \\
70(63,1)\end{array}$ & 0,417 & $\begin{array}{l}18(75) \\
88(79,3)\end{array}$ & $\begin{array}{l}6(25) \\
23(20,7)\end{array}$ & 0,643 \\
\hline $\begin{array}{l}\text { Hematokrit } \\
\text { - Meningkat } \\
\text { - Normal }\end{array}$ & $\begin{array}{l}4(22,2) \\
48(41)\end{array}$ & $\begin{array}{l}14(77,8) \\
69(59)\end{array}$ & 0,127 & $\begin{array}{l}12(66,7) \\
94(80,3)\end{array}$ & $\begin{array}{l}6(33,3) \\
23(19,7)\end{array}$ & 0,118 \\
\hline $\begin{array}{l}\text { Fibrinogen } \\
\text { - Meningkat } \\
\text { - Normal }\end{array}$ & $\begin{array}{l}30(32,6) \\
22(51,2)\end{array}$ & $\begin{array}{l}62(67,4) \\
21(48,8)\end{array}$ & $0,039 *$ & $\begin{array}{l}69(75) \\
37(86)\end{array}$ & $\begin{array}{l}23(25) \\
6(14)\end{array}$ & 0,145 \\
\hline $\begin{array}{l}\text { Dislipidemia } \\
\text { - Ya } \\
\text { - Tidak }\end{array}$ & $\begin{array}{l}39(37,1) \\
13(43,3)\end{array}$ & $\begin{array}{l}66(62,9) \\
17(56,7)\end{array}$ & 0,539 & $\begin{array}{l}78(74,3) \\
28(93,3)\end{array}$ & $\begin{array}{l}27(25,7) \\
2(6,7)\end{array}$ & $0,025^{*}$ \\
\hline
\end{tabular}

IL-6: interleukin-6; NSE: neuron specific enolase.

dkk mendapatkan bahwa DM meningkatkan risiko subjek menjadi dependen atau meninggal pada 12 dan 18 bulan dengan skala mRS. ${ }^{17}$ Namun, penelitian ini tidak menunjukkan hubungan antara DM dengan nilai mRS pada 1 bulan. Hal ini menandakan bahwa selain berhubungan dengan luaran stroke jangka panjang, DM pada pasien juga berhubungan dengan luaran fungsional subjek jangka pendek.

Kadar fibrinogen tinggi berhubungan dengan luaran mRS dan NIHSS buruk. Hasil penelitian ini sesuai dengan Swarowska dkk, bahwa peningkatan kadar fibrinogen merupakan prediktor luaran buruk pada subjek stroke. Pada stroke iskemik, terdapat inflamasi yang menyebabkan diproduksinya protein fase akut. Fibrinogen merupakan protein fase akut pada inflamasi. Meningkatnya kadar fibrinogen dalam darah dapat memperburuk luaran stroke iskemik akut. ${ }^{18}$

Dalam penelitian ini, setelah dilakukan penyesuaian (adjusting) risiko relatif kadar IL-6 dengan faktor-faktor lain yang memengaruhi terhadap skor mRS 1 bulan dan NIHSS 7 hari, belum dapat diambil kesimpulan pengaruh kadar IL-6 dengan perburukan pada stroke iskemik akut. Seluruh RR kadar IL-6 terhadap mRS dan NIHSS yang di adjust dengan perancu (Tabel 4 dan 5) mencakup angka 1 menunjukkan hasil yang inkonklusif. Hal ini berbeda dengan Kusumaningrum yang menyatakan bahwa kadar IL-6 yang tinggi memiliki rasio Odds perbaikan mRS bulan pertama dan ketiga sebesar $9 \mathrm{x}$ dibandingkan kadar IL-6 normal, yaitu 10x. ${ }^{9}$

Demikian pula Shaafi dkk menunjukkan bahwa IL-6 pada stroke iskemik akut berkorelasi 
Tabel 5. Hubungan Kadar IL-6 terhadap Perubahan Skor NIHSS $(n=135)$

\begin{tabular}{|c|c|c|c|c|}
\hline \multirow[b]{2}{*}{ IL-6 } & \multicolumn{2}{|c|}{ NIHSS } & \multirow{2}{*}{$\begin{array}{c}\text { RR } \\
\text { (IK } \\
\text { 95\%)* }\end{array}$} & \multirow{2}{*}{$\begin{array}{c}\text { RR } \\
\text { (IK } \\
95 \%)^{* * *}\end{array}$} \\
\hline & $\begin{array}{c}\text { Perbaikan } \\
\text { n (\%) }\end{array}$ & $\begin{array}{c}\text { Perburukan } \\
\text { n (\%) }\end{array}$ & & \\
\hline Normal & $19(46)$ & $33(35)$ & 1,279 & 1,363 \\
\hline Tinggi & $22(54)$ & $61(65)$ & $\begin{array}{l}(0,581- \\
2,812)\end{array}$ & $\begin{array}{c}(0,586- \\
3,159)\end{array}$ \\
\hline
\end{tabular}

*Risiko relatif yang disesuaikan dengan mengontrol hematokrit, fibrinogen, dan dislipidemia; **Risiko relatif yang disesuaikan setelah mengontrol variabel jenis kelamin, status diabetes melitus, hematokrit, fibrinogen dan dyslipidemia; IL-6: interleukin-6; NIHSS: National Institute of Health Stroke Scale; RR: risiko relatif; IK: interval kepercayaan.

dengan luaran stroke dan luas infark. Produksi IL-6 oleh sel-sel otak yang mengalami infark cukup bermakna sehingga cukup adekuat untuk dijadikan penanda prognosis subjek stroke iskemik akut. ${ }^{19}$ Dalam penelitian sebelumnya, dilakukan metode kasus-kontrol dan kohort prospektif tanpa melibatkan faktor-faktor perancu lainnya. Dalam penelitian ini, dilakukan adjusting terhadap faktor-faktor perancu tidak seperti penelitian-penelitian sebelumnya. Perbedaan metodologi ini yang dapat menjelaskan perbedaan hasil yang didapatkan

Dalam penelitian ini, NSE tidak memiliki hubungan dengan luaran mRS dan NIHSS. Proporsi perburukan pada subjek relatif sama pada subjek dengan kadar NSE rendah ataupun tinggi. Hasil ini berbeda dengan Zaheer dkk, bahwa terdapat hubungan antara NSE pada hari pertama dengan mRS pada 1 bulan setelah awitan stroke. ${ }^{7}$ Namun, penelitian Kaca-Orynska dkk menunjukkan tidak ada hubungan antara NSE hari pertama dengan luaran stroke. $^{20}$

Nilai NSE dinilai kurang spesifik dalam menjadi faktor prediktor dalam luaran stroke karena NSE merupakan enzim yang berada di proses glikolisis dan meningkat pada saat terjadi kerusakan sel otak. Namun, terdapat kemungkinan kembalinya fungsi sel otak setelah terapi reperfusi pada daerah iskemik yang menyebabkan tidak ada hubungan kadar NSE dengan luaran stroke iskemik. Hal ini juga dinyatakan oleh Rasyid bahwa meskipun kadar NSE normal, secara klinis didapati perburukan pada skor NIHSS, tetapi kadar NSE normal menunjukkan kerusakan sel tingkat seluler, yaitu daerah penumbra iskemik belum mengalami kematian sel. Dengan
Tabel 6. Nilai RR Adjusted Kadar IL-6 dengan Faktor yang Berinteraksi terhadap mRS $(n=135)$

\begin{tabular}{lcc}
\hline \multirow{2}{*}{ Jenis Kelamin } & \multicolumn{2}{c}{ Merokok } \\
\cline { 2 - 3 } & Ya (IK 95\%) & Tidak (IK 95\%) \\
\hline Perempuan & $181,5(0,43-77029)$ & $6,7(0,2-200,9)$ \\
Laki-laki & $16,5(0,3-840,6)$ & $0,6(0,2-2,2)$ \\
\hline $\begin{array}{l}\text { RR: risiko relatif; } \\
\text { kepercayaan. }\end{array}$
\end{tabular}

terapi yang cepat dan optimal, sel yang mengalami cedera masih dapat diselamatkan. ${ }^{11}$

Selain itu, terdapat perbedaan karakteristik subjek antara penelitian ini dengan penelitian Zaheer dkk serta Kaca-Orynska dkk. ${ }^{11,20}$ Dalam kedua penelitian tersebut, seluruh pasien dengan stroke iskemik dianalisis. Sementara dalam penelitian ini, hanya pasien dengan stroke iskemik subtipe PACS dan LACS saja yang dilakukan analisis. Belum pernah dilakukan penelitian mengenai perbedaan kadar NSE pada berbagai subtipe stroke. Dari penelitian ini, didapatkan bahwa pada pasien dengan subtipe stroke PACS dan LACS, tidak terdapat pengaruh tingkat kadar NSE dengan luaran stroke iskemik akut.

Telah diketahui bahwa IL-6 telah menjadi penanda prognosis yang baik dalam luaran stroke iskemik akut. Penelitian ini berusaha menginvestigasi seberapa besar efek luaran buruk stroke iskemik akut dilihat dari peningkatan IL-6. Dari analisis RR adjusted pada penelitian ini, didapatkan bahwa jenis kelamin perempuan dan merokok dapat meningkatkan risiko luaran buruk pada stroke iskemik akut. Namun, risiko relatif yang diinvestigasi dalam penelitian ini mencakup angka 1 yang berarti belum dapat diambil kesimpulan mengenai rasio Odds IL-6 terhadap luaran stroke iskemik akut.

Penelitian ini memiliki keterbatasan, yaitu belum dilakukan penilaian IL-6 dan NSE dengan luaran stroke pada seluruh jenis stroke. Hal ini mengingat adanya perbedaan luas infark dan keparahan stroke diantara berbagai tipe stroke. Untuk ke depannya, dapat dilakukan penilaian kadar IL-6 dan NSE terhadap luaran stroke akut berbagai tipe.

\section{KESIMPULAN}

Kadar IL-6 belum bisa dijadikan penanda prognosis luaran stroke iskemik akut subtipe PACS dan LACS terhadap skor NIHSS 7 hari dan mRS 1 bulan meskipun terdapat kecenderungan luaran buruk pada subjek dengan kadar IL-6 tinggi. Serum 
NSE tidak berhubungan dengan luaran stroke iskemik akut.

\section{DAFTAR PUSTAKA}

1. Powers WJ. Cerebral blood flow and metabolism: regulation of pathophysiology in cerebrovascular disease. Dalam: Grotta JC AG, Broderick JP, Kasner SE, Lo EH, Mendelow AD, editor. Stroke: Pathophysiology, diagnosis, and management. Edisi ke-6. New York: Elsevier; 2016. h. 28-46.

2. Tobin MK, Bonds JA, Minshall RD, Pelligrino DA, Testai FD, Lazarov O. Neurogenesis and inflammation after ischemic stroke: what is known and where we go from here. J Cereb Blood Flow Metab. 2014;34(10):1573-84.

3. Cojocaru IM, Cojocaru M, Tananescu R, Ilescu IU, Dumitrascu L, Silosi I. Expression of IL6 activity in patients with acute ischemic stroke. Rom J Intern Med. 2009;47(4):393-6.

4. Benakis CH, Hirt L, Du-Pasquier RA. Inflammation and stroke. CardioMed. 2009;12(5):143-50.

5. Shenhar-Tsarfaty S, Assayag EB, Bova I, Shopin L, Berliner S, Shapira I, dkk. Early signaling of inflammation in acute ischemic stroke: clinical and rheological implications. Thromb Res. 2008;1222(2):167-73.

6. Isgro MA, Bottoni P, Scatena R. Neuron-specific enolase as a biomarker: biochemical and clinical aspects. Dalam: Scatena R, editor. Advances in cancer biomarkers. advances in experimental medicine and biology. Volume 867. Dordrecht: Springer; 2015. h. 125-43.

7. Zaheer S, Beg M, Rizvi I, Islam N, Ullah E, Akhtar $\mathrm{N}$. Correlation between neuron specific enolase and functional neurological outcome in patients of acute ischemic stroke. Ann Indian Acad Neurol. 2013;16(4):504-8.

8. Chiba T, Umegaki K. Pivotal roles of monocytes/ macrophages in stroke. Mediators Inflamm. 2013;2013:1-10.

9. Kusumaningrum W. Peran Interleukin 6 dalam menentukan keluaran modified Rankin Scale pada sirkulasi parsial anterior stroke iskemik akut [tesis]. Jakarta: Universitas Indonesia; 2014.
10. Anand N, Stead L. Neuron-specific enolase as a marker for acute ischemic stroke: a sytematic review. Cerebrovasc Dis. 2005;20:213-9.

11. Rasyid A. Efektivitas mikropapiler digital sebagai alat ukur nilai viskositas darah untuk prediksi prognosis stroke iskemik akut [disertasi]. Jakarta: Universitas Indonesia; 2014.

12. Rasyid A, Soertidewi L. Unit stroke manajemen stroke komprehensif. Jakarta: Balai Penerbit FKUI; 2007. h. 64-71.

13. Misbach J, Ali W. Stroke in Indonesia: A first large prospective hospitalbased study of acute stroke in 28 hospitals in Indonesia. J Clin Neurosci. 2000;8(3):245-9.

14. Arboix A. Cardiovascular risk factors for acute stroke: risk profiles in the different subtypes of ischemic stroke. World J Clin Cases. 2015;3(5):418-29.

15. Zhong C, Lv L, Liu C, Zhao L, Zhou M, Sun W, dkk. High homocysteine and blood pressure related to poor outcome of acute ischemia stroke in chinese population. Plos One. 2014;9(9):e107498.

16. Yudiarto F, Machfoed MH, Amir D, Ong A, Siswanto S. Hypertension is the most Risk Factor Stroke in Indonesia Stroke Registry. Neurology. 2017;88(Supl 16):P3-263.

17. Nayak AR, Badar SR, Lande N, Kawle AP, Kabra DP, Chandak NH, dkk. Prediction of outcome in diabetic acute ischemic stroke patients: a hospital-based pilot study report. Ann Neurosci. 2016;23:199-208.

18. Swarowska M, Janowska A, Polczak A, KlimkowiczMrowiec A, Pera J, Slowik A, dkk. The sustained increase of plasma fibrinogen during ischemic stroke predicts worse outcome independently of baseline fibrinogen level. Inflammation. 2014;37(4):1142-7.

19. Shaafi S, Sharifipour E, Rahmanifar R, Hejazi SS, Andalib S, Nikanfar M, dkk. Interleukin-6, a reliable prognostic factor for ischemic stroke. Iran J Neurol. 2014;13(2):70-6.

20. Kaca-Orynska M, Tomasiuk R, Friedman A. Neuronspecific enolase and $\mathrm{S} 100 \mathrm{~B}$ protein as predictors of outcome in ischaemic stroke. Neurol Neurochir Pol. 2010;44(5):459-63. 